\title{
AGWA: The Automated Geospatial Watershed Assessment Tool to Inform Rangeland Management
}

\author{
By David C. Goodrich, D. Phillip Guertin, I. Shea Burns, \\ Mark A. Nearing, Jeffry J. Stone, Haiyan Wei, Philip \\ Heilman, Mariano Hernandez, Ken Spaeth, Fred Pierson, \\ Ginger B. Paige, Scott N. Miller, William G. Kepner, George \\ Ruyle, Mitchel P. McClaran, Mark Weltz, and Leonard Jolley
}

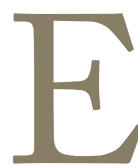

ffective rangeland management requires the ability to assess the potential impacts of management actions on soil erosion and sediment yield at both the hillslope and watershed scales. Many of the current tools ${ }^{1}$ for assessing and evaluating the effects of rangeland management practices on soil and water resources originally were developed for traditional cropland agricultural practices. These tools and models assumed a uniform vegetation distribution and surface cover across the landscape, which was inadequate to represent typical rangeland conditions. Current technologies also do not directly use information at the ecological site level. In this article, we focus on a Decision Support Tool (DST) that incorporates ecological concepts and rangeland management practices, uses readily available data, and is designed to represent rangeland hydrologic and erosion processes. The recently developed RHEM (Rangeland Hydrology and Erosion Model $^{2}$ ) and the Automated Geospatial Watershed Assessment tool $\left(\mathrm{AGWA}^{3}\right.$ ) form the foundation of this DST. RHEM is applicable at the hillslope scale, and when executed, completes a simulation for a single hillslope. AGWA, via the KINEROS2 watershed model, executes RHEM for all hillslopes within a watershed. Runoff and sediment are routed through channels draining the hillslopes, enabling rapid watershed scale assessments.

RHEM is an event-based derivation of an existing model (Water Erosion Prediction Project ${ }^{4}$ ) which uses a new splash and sheet erosion equation ${ }^{5}$ developed specifically for rangeland systems and tested against rangeland data. It is designed to use data that are routinely collected by rangeland managers and in national monitoring programs such as the Natural Resources Conservation Service (NRCS) National Resource Inventory (NRI). It estimates runoff, erosion by water, and sediment delivery rates (see Glossary of Terms). RHEM incorporates the interaction between hydrology and erosion processes, ground cover, plant abundance (canopy cover), and plant growth forms (i.e., sodgrass, bunchgrass, shrubs, and forbs). The flow chart depicted in Figure 1 illustrates the necessary inputs and model execution procedures for the model. RHEM can be executed via the internet using a user-interface. ${ }^{i}$ Inputs provided by the user include storm

\section{Glossary of Terms}

Erosion: the process of eroding or being eroded by wind, water, or other natural agents.

Hillslope: the flanks of valleys and the margins of eroding uplands.

Runoff: rainfall not absorbed by soil.

Sediment transport rates: the amount of sediment moved by overland flow or a stream in a given time, measured by dry weight or by volume.

Watershed: extent or an area of land where surface water from rain and melting snow or ice converges to a single point.

'Access RHEM on Web site available at: http://apps.tucson.ars.ag.gov/ rhem/. 


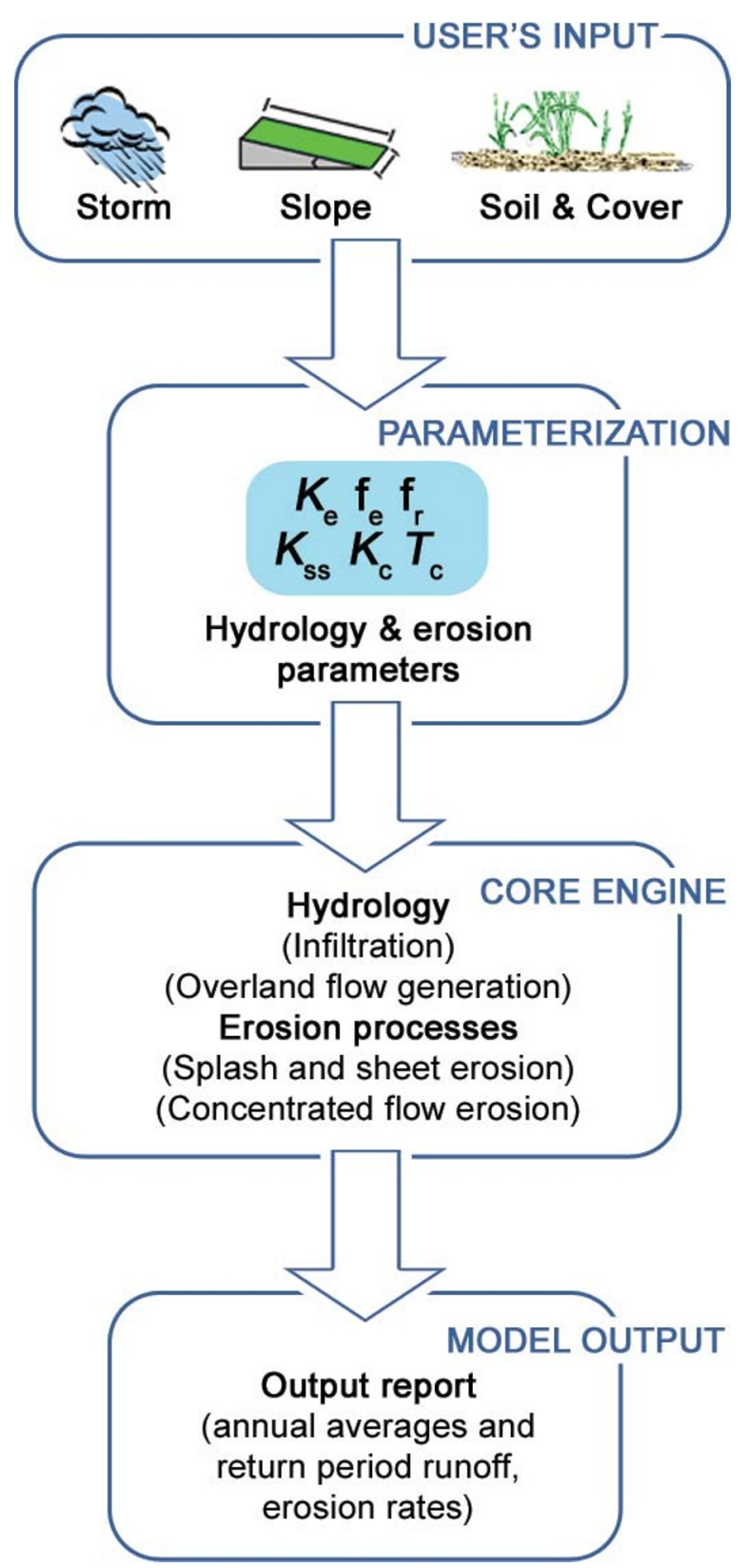

Figure 1. Rangeland Hydrology and Erosion Model (RHEM) flowchart.

characteristics, hillslope shape and slope, dominant plant type, soil cover characteristics (plant canopy, plant base at ground level, rock, litter, cryptogams/microbioitc crusts), and soil texture. Storm characteristics derived from hundreds of long-term climate stations distributed over the western United Sates for various return periods also are available on the web site.

RHEM model simulation inputs and outputs are displayed in tabular and graphical form and multiple runs can be compared to assess how changes in cover characteristics from management practices will influence runoff and sediment (although storm size is the primary determinate of overall erosion and sediment loss). In terms of adjustable

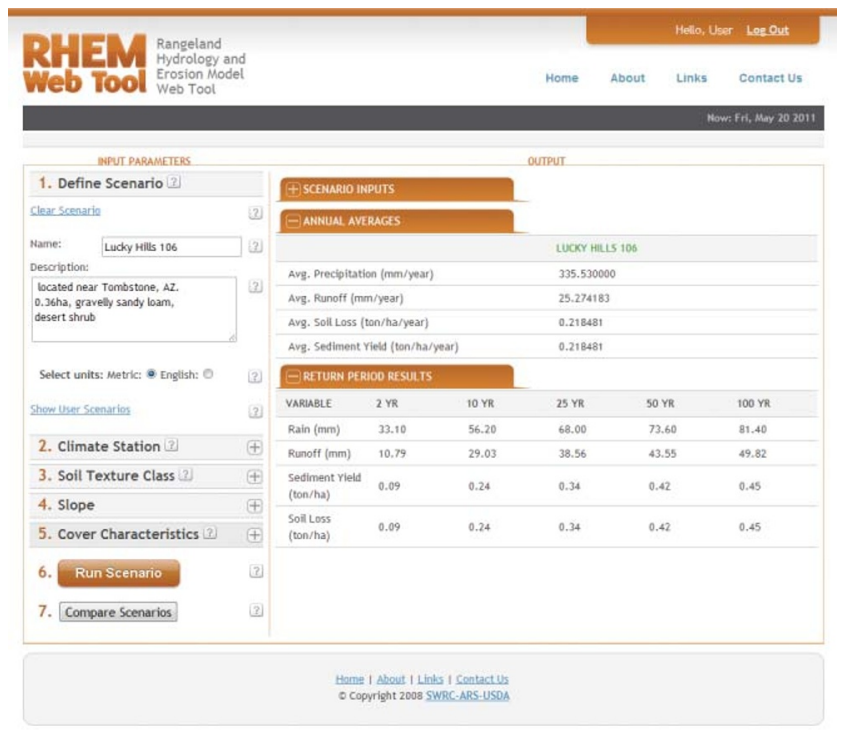

Figure 2. Rangeland Hydrology and Erosion Model (RHEM) internet output for the 0.36 ha Lucky Hills 106 watershed located near Tombstone in southeastern Arizona.

variables, canopy cover and ground cover are the most sensitive parameters. Note that ground cover equals the sum of basal plant area, litter, rock, and cryptogams both outside and under the canopy cover. Litter is defined as dead vegetation in contact with the soil surface. Soil texture also is important, and model results are sensitive to dominant plant growth form. ${ }^{2,6}$ RHEM allows the user to estimate the vulnerability of a site to soil erosion based on the risk of experiencing a runoff event with a given magnitude (e.g., 10-, 25-, or 50-year return period storm events).

To illustrate, RHEM was applied to the 0.36-ha Lucky Hills 106 watershed located near Tombstone in southeastern Arizona. The soil in Lucky Hills 106 is gravelly sandy loam, the vegetation is dominated by desert shrub and the average slope of the watershed is $8.9 \%$. Canopy cover during the rainy season is approximately $25 \%$, and approximately two-thirds of the ground area is covered with rock. Using the Tombstone climate station selected from the RHEM interface, the simulated average annual runoff is $25.3 \mathrm{~mm}$ per year, and the average annual soil loss is 0.22 tons per ha per year. The RHEM web page output for this example is illustrated in Figure 2, along with model results for storms with average return periods of 2, 10, 25, 50, and 100 years. Using RHEM allows land managers to be proactive in preventing accelerated soil loss on rangelands by targeting areas for conservation management that are most vulnerable to soil erosion.

KINEROS2 $2^{7,8}$ is a watershed-based model which can identify hillslopes that might be vulnerable to soil erosion over an entire watershed. It iteratively simulates all hillslopes in a watershed using RHEM, as well as modeling runoff, erosion, and sediment transport in the channels draining the hillslopes. KINEROS2 is an event-based model that 


\section{AGWA Inputs and Outputs}

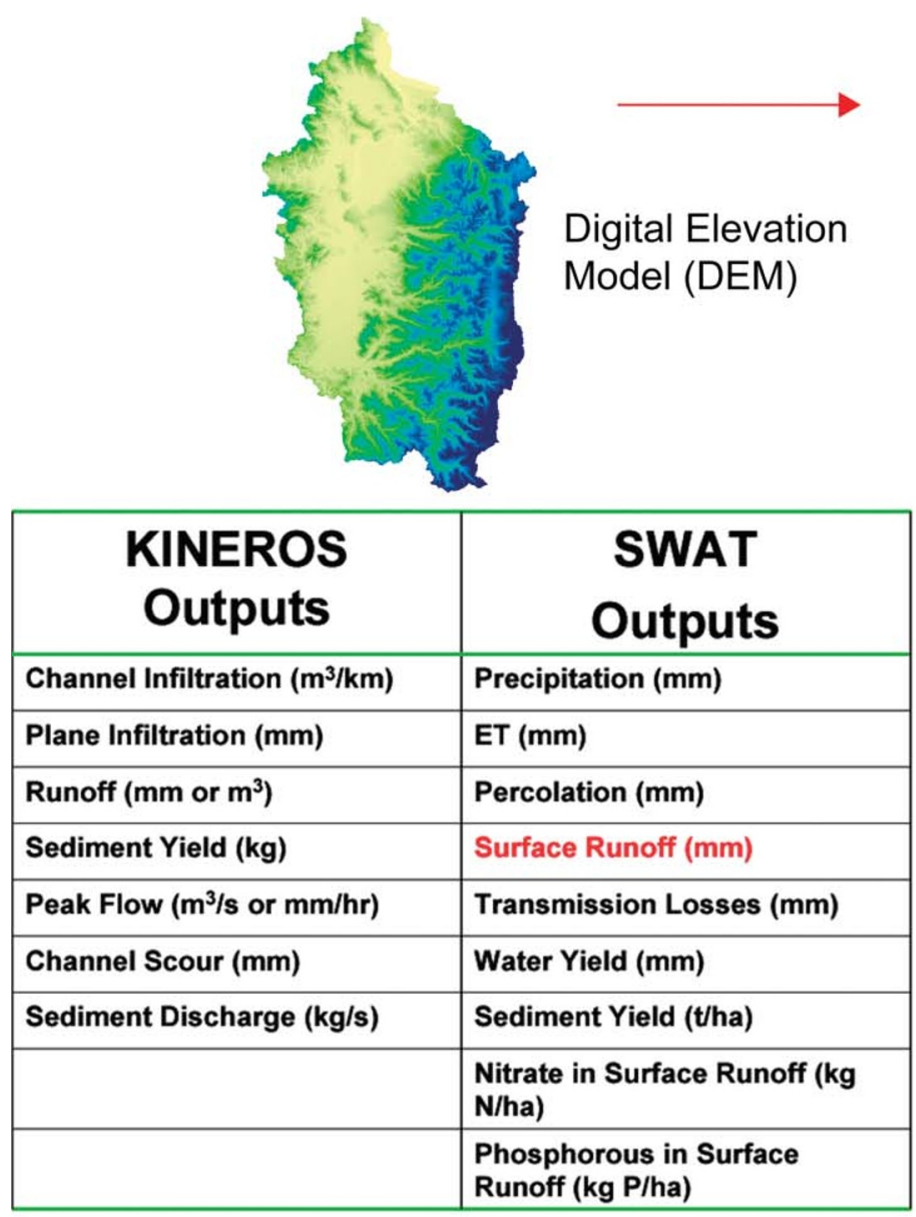

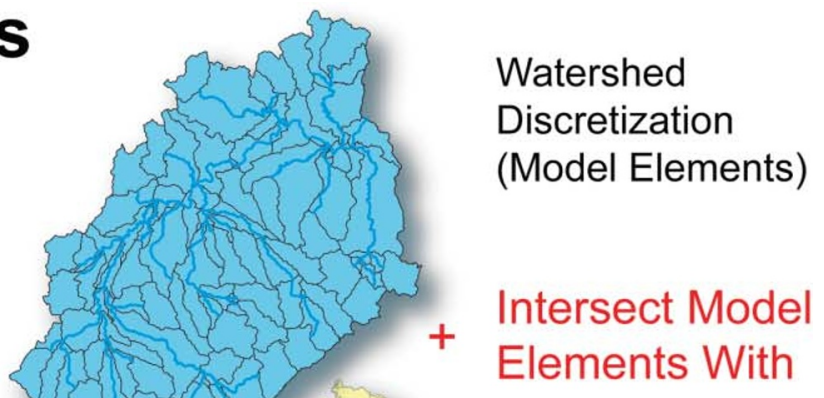

Figure 3. An illustration of the Automated Geospatial Watershed Assessment (AGWA) process to parameterize the KINEROS2 and Soil Water Assessment Tool (SWAT) hydrologic models based on topography, soils, and land-cover Geospatial Geographic Information Systems (GIS) data. A digital elevation model (DEM) is used to subdivide the watershed into hillslope and channel model elements, each of which are parameterized according to their soil, topographic, and land-cover characteristics. Any of the outputs listed under the two models can be mapped back into hillslope or channel model elements. In this case the surface runoff in depth $(\mathrm{mm})$ over the watershed is illustrated.

conceptualizes a watershed as a series of hillslope and channel modeling elements where the output from upstream elements becomes the input to downstream elements. The model has been validated and applied in a wide variety of applications and environments. ${ }^{8}$ To more easily apply RHEM and KINEROS2 to numerous watersheds, the AGWA ${ }^{3, \mathrm{ii}}$ tool was developed.

AGWA is an ArcGIS interface to support data organization, model parameterization, integration, and visualization for KINEROS2, RHEM, and the Soil Water Assessment Tool (SWAT ${ }^{9}$ ) model. The application of these three models allows AGWA to conduct hydrologic modeling and watershed assessments at multiple temporal and spatial scales. Unlike

iAccess the AGWA tool on Web site available at: www.tucson.ars.ag.gov/ agwa. many models, KINEROS2 also enables users to explicitly place best management practices (BMPs) in their geographically correct position (e.g., riparian buffer strips, grazing allotments that can cover multiple hillslopes and small watersheds) and model runoff-runon effects of these BMPs. At present, BMPs are inserted manually by creating a new overland flow-modeling element with the cover characteristics of the BMP. Inputs for AGWA are nationally available, and consist of topographic information, soils, land cover, and climate or storm input. AGWA's current outputs are runoff, erosion and sediment yield, and several water quality variables for SWAT (Fig. 3). RHEM, KINEROS2, and AGWA are being used in the rangeland USDA Conservation Effects Assessment Project (CEAP). ${ }^{10}$

All of the required initial modeling parameters automatically are generated by AGWA from topography, soils, and land cover/landuse Geographic Information Systems (GIS) 
data layers. Through an intuitive interface the user selects an outlet from which AGWA delineates and subdivides the targeted watershed using a Digital Elevation Model (DEM; Fig. 3). The user specifies a channel support area (CSA - the minimum drainage area required to initiate the head of a first-order channel) to adjust the level of model complexity. The smaller the CSA, the greater the number of model elements. The watershed model elements (hillslope and channel elements) then are combined with soils and land cover data layers to derive the requisite model input parameters. AGWA currently can use nationally available soils databases from the NRCS and globally available from the United Nations Food and Agricultural Organization (FAO) as well as nationally available National Land Cover Data (NLCD), North American Landscape Characterization (NALC), and Gap Analysis Program (GAP) land cover/land use data. At present, land cover is assumed to be at an average condition and lookup tables based on experimental data and published values are used to estimate initial infiltration, roughness, and erosion parameters for each model element based on area-weighted averages of cover and soil properties.

Users also can provide their own soil and land cover/use data as GIS layers or edit any of the values for individual modeling elements based on their own monitoring data or detailed ranch plans. As ecological sites and state and transition descriptions become nationally available in the future, better plant abundance and soil cover information will be available to parameterize RHEM and the hillslope hydrology and erosion in AGWA-KINEROS2. NRCS is developing a national GIS database of ecosites to describe typical vegetation and land cover characteristics within each site for a given state. We will work closely with NRCS to use these state conditions to estimate initial infiltration and erosion model parameters.

Built into AGWA are digitized and interpolated versions of the National Oceanographic and Atmospheric Administration (NOAA) technical publication 40 (TP40) rainfall frequency atlas maps. These maps enable users to select storms of various durations and frequencies. Users also can specify their own storm type or enter observed precipitation data. Once parameters for the model elements have been estimated, the model is executed, and the results are imported into ArcGIS for visualization. AGWA, like RHEM, can compare results from multiple simulations to examine relative change from alternative input scenarios (e.g., climate/storm change, management practices). AGWA also has other features including pre- and postfire watershed assessment, options for user-defined land cover change, implementation of streamside buffer zones, and installation of retention/detention structures. ${ }^{8}$ This allows managers to identify potential problem areas where additional monitoring can be undertaken or mitigation activities can be focused. For example, if the model predicts that a given hillslope has a high rate of erosion, the rancher might want to deploy a management practice (e.g., brush removal, grazing reduction) that would result either in a change in state or an increase in vegetation cover to reduce erosion.

As with RHEM, storm inputs are the most important drivers for runoff and erosion in AGWA. Other sensitive parameters relate to soil and vegetation cover data whose relative importance varies by dominant plant form. For watershed assessments, AGWA includes channels with associated parameters related to cross-section geometry, hydraulic roughness, and channel substrate for infiltration and transmission losses. Because DEM data of $10-\mathrm{m}$ grid spacing or greater is typically too coarse to define channel geometry, the cross-section geometry estimates are initially defined in AGWA by statistical regression relationships developed from field observations and metrics derived from the digital elevation data that are typical of channels found in Major Land Resource Area (MLRA) 41 in southeastern Arizona. ${ }^{11}$ It should be stressed that these relationships were developed over limited regions and therefore are not applicable universally. Improved results can be obtained with local-user defined (estimated or surveyed) channel crosssection data. It should also be noted that all of the model parameters estimated by AGWA should be viewed as approximate, initial estimates. If watershed input and output observations are not available to calibrate the model, quantitative estimates of runoff and erosion will have a high degree of uncertainty. In this situation it is best to use AGWA for relative change analysis, i.e., to estimate the direction and relative percentage change in response to a management practice.

\section{Applying AGWA}

AGWA was applied on a small subwatershed of the Cienega Creek Watershed in southeastern Arizona (Fig. 4). Based on rangeland monitoring data, two rangeland scenarios are described for the Loamy Upland Ecological Site:

I. Near reference state condition (historic climax plant community) with high plant cover (canopy cover $=78 \%$; ground cover $=72 \%$ ), and

II. Low plant cover-the Mesquite-Native state (canopy cover $=25 \%$; ground cover $=40 \%$ ).

The 783 acre watershed has variable terrain and soils but nearly uniform vegetation. The risk of erosion and runoff from the watershed was assessed for a range of 1-hour rainfall events ranging from the 2-year to 100-year storms (1.29 and 2.9 inches for the 2- and 100-year events, respectively). RHEM was used to model the runoff and erosion from the hillslope elements and channel routing and sediment transport was simulated with existing channel routines in KINEROS2. This provided an integrated modeling platform to support both hillslope and watershed assessments for runoff and erosion.

Figure 4 depicts the spatial distribution of erosion and sediment yield from a 1-hour, 10-year storm across the watershed identifying areas at risk for the high (left) and low (right) plant cover conditions. Table 1 provides aggregate 


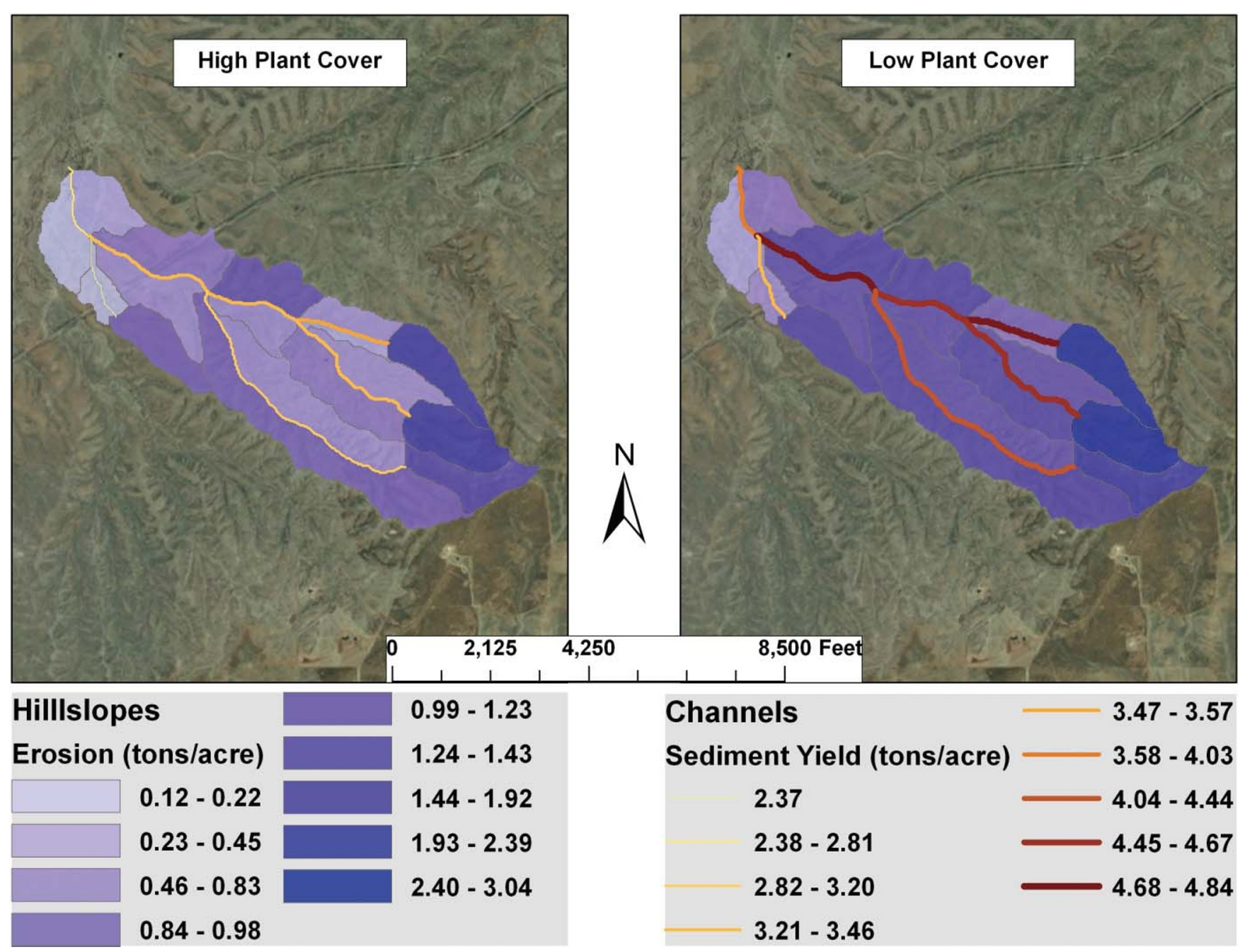

Figure 4. Hillslope and channel erosion in tons per acre for each hillslope and channel model element in a subwatershed (783 acres) of the Cienega Creek Watershed in southeast Arizona for a 1-hour storm occurring on average, once every 10 years.

erosion, runoff and infiltration assessments for the hillslopes. Hillslope erosion increased $77 \%$ on the watershed between the high and low cover condition classes for the 2-year storm, whereas hillslope erosion increased 53\% for the 100 year storm. The maximum erosion rate from an individual hillslope element in low cover condition was 4.9 tons per acre for the 100-year storm. However, we'd like to reiterate the caution noted above regarding using results from an uncalibrated model simulation: It is better to judge the relative change in simulation results between pre- and postmanagement cases. Figure 4 also illustrates the variability in sediment yield that can occur in a semiarid watershed with ephemeral streams. The center of the watershed has higher sediment loads than the watershed outlet, indicating that sediment can be deposited within the watershed during smaller events. Hillslope runoff increased $51 \%$ between the high and low cover condition classes for the 2-year storm, but only increased by $19 \%$ for the 100 -year storm. Greater increases in runoff from the smaller, more frequent rainfall events can cause significant channel impairment within the watershed. There are potential long-term implications of these results as well for overall plant productivity. Infiltration is substantially greater for the high vs. low cover condition ( $78 \%$ and $95 \%$ for the 2 - and 100 -year storms, respectively). This difference in infiltration would eventually influence plant growth efficiency $(\mathrm{kg} / \mathrm{ha} / \mathrm{cm}$ of precipitation) as more rainfall moves into the soil and is available for plants vs. into the channel and away from the plants. These results illustrate how AGWA can be used to identify areas of a watershed where the greatest reduction in runoff and erosion would occur if conservation management converts low cover to high cover.

\section{Future Innovations}

Additions to transform the current AGWA tool into a comprehensive Automated Geospatial Watershed Assessment Tool for Rangelands that will operate at multiple scales are underway. This version of AGWA will have a user-friendly 


\begin{tabular}{|c|c|c|c|c|c|c|}
\hline \multirow[b]{2}{*}{$\begin{array}{l}\text { 1-hour event } \\
\text { occurring every }\end{array}$} & \multicolumn{3}{|c|}{ High plant cover } & \multicolumn{3}{|c|}{ Low plant cover } \\
\hline & $\begin{array}{l}\text { Erosion (tons } \\
\text { per acre) }\end{array}$ & $\begin{array}{c}\text { Runoff } \\
\text { (acre-feet) }\end{array}$ & $\begin{array}{l}\text { Infiltration } \\
\text { (acre-feet) }\end{array}$ & $\begin{array}{l}\text { Erosion } \\
\text { (tons per acre) }\end{array}$ & $\begin{array}{c}\text { Runoff } \\
\text { (acre-feet) }\end{array}$ & $\begin{array}{l}\text { Infiltration } \\
\text { (acre-feet) }\end{array}$ \\
\hline 2 years & 0.53 & 38.27 & 44.08 & 0.94 & 57.82 & 24.68 \\
\hline 5 years & 0.84 & 60.81 & 47.24 & 1.36 & 82.46 & 25.69 \\
\hline 10 years & 1.06 & 76.90 & 49.12 & 1.67 & 99.92 & 26.21 \\
\hline 25 years & 1.34 & 98.20 & 50.91 & 2.08 & 122.49 & 26.74 \\
\hline 50 years & 1.57 & 115.08 & 52.08 & 2.40 & 140.16 & 27.06 \\
\hline 100 years & 1.82 & 134.57 & 53.01 & 2.79 & 160.43 & 27.39 \\
\hline
\end{tabular}

interface so that resource managers, ranchers, and other stakeholders can increase their knowledge of watershed processes and evaluate, individually or as a group, how various rangeland management practices, and climate or fire induced changes can affect soil quality, water quantity, water quality, and wildlife habitat. Additional capabilities that will soon be available include:

- The representation and modeling of fire and drought effects;

- Parameterization procedures based on Ecological Site Descriptions and State-and-Transition Models;

- Tools for users to enter and modify their water locations, fences, and buffers within the GIS interface to develop a ranch management plan;

- An economic analysis toolkit which includes the management costs and effects of state transitions (described in more detail below); and,

- A web-based version of AGWA.

The economic analysis toolkit will be based on the current version of the economic assessment component embedded in the rangeland spatial decision support system.iii This system calculates a ranch (watershed) budget based on the structure of a cow-calf herd, fixed and variable costs, costs of conservation measures, and price of calves/stockers. This approach links grazing to vegetation biomass, cover, erosion, and sediment yield. The logic behind this approach is that in the short- to medium-term a rancher either can harvest vegetation, converting it to pounds of beef, or leave it to protect the soil from erosion. AGWA results can help determine where on the landscape one can safely maximize vegetation harvest and where to reduce harvesting to produce significant erosion control and longer-term productivity improvements. The coupled economic analysis will provide an assessment of the costs for the rancher and NRCS or land-owning agency for a set of management practices to conserve soil and reduce sediment yield.

iii Access the rangeland Spatial Decision Support System at Web site available at: http://tucson.ars.ag.gov/sdss/.
The analysis will provide cost-effectiveness, rather than a cost-benefit estimate. This approach is chosen because, rather than estimating offsite benefits from sediment yield reductions, the limits on erosion and sediment yield will come from a public land agency's and/or rancher's sustainability goals, rangeland erosion tolerance concepts, proper functioning condition concepts, thresholds from quantified rangeland health procedures, or sediment abatement goals from total maximum daily load (TMDL) planning.

The current RHEM and AGWA tools, as well as those in development, will support the analysis of alternative management systems as well as their placement in a watershed to reduce conservation investments and increase cumulative conservation benefits over a range of scales (i.e., pasture to landscape). They will link rangeland field measurements directly to decision-making for public land management and improved conservation programs. Register to download AGWA and receive updates at the AGWA web site.

\section{Acknowledgments}

Carl Unkrich, Tim Keefer, and the anonymous reviewers are gratefully acknowledged for their valuable reviews and comments.

\section{References}

1. Spaeth, K. E., F. B. Pierson, M. A. Weltz, and W. H. BLAckBURn. 2003. Evaluation of USLE and RUSLE estimated soil loss on rangeland. Journal of Range Management 56(3):234246.

2. Nearing, M. A., H. Wei, J. J. Stone, F. B. Pierson, K. E. Spaeth, M. A. Weltz, D. C. Flanagan, and M. Hernandez. 2011. A rangeland hydrology and erosion model. Transactions of the American Society of Agricultural and Biological Engineers 53(3):1-5.

3. Miller, S. N., D. J. Semmens, D. C. Goodrich, M. Hernandez, R. C. Miller, W. G. Kepner, and D. P. Guertin. 2007. The Automated Geospatial Watershed Assessment tool. Environmental Modeling and Software 22:365-377.

\footnotetext{
"Web site available at: http://www.tucson.ars.ag.gov/agwa.
} 
4. Flanagan, D. C., and M. A. Nearing. 1995. USDA-Water Erosion Prediction project: Hillslope profile and watershed model documentation. NSERL Report No. 10. West Lafayette, IN: USDA-ARS National Soil Erosion Research Laboratory. $287 \mathrm{p}$.

5. Wei, H., M. A. Nearing, J. J. Stone, D. P. Guertin, K. W. Spaeth, F. Pierson, M. H. Nichols, and C. A. Moffett. 2009. A new splash and sheet erosion equation for rangelands. Soil Science of America Journal 73:1386-1392.

6. Wei, H., M. A. Nearing, and J. J. Stone. 2007. A new sensitivity analysis framework for model evaluation and improvement using a case study of the Rangeland Hydrology and Erosion Model. Transactions of the American Society of Agricultural and Biological Engineers 50(3):945-953.

7. Smith, R. E., D. C. Goodrich, D. A. Woolhiser, and C. L. UNKRICH. 1995. KINEROS-a kinematic runoff and erosion model. Chapter 20. In V. P. Singh (ED.). Computer Models of Watershed Hydrology. Highlands Ranch, CO: Water Resources Publications. p. 697-732.

8. Goodrich, D. C., S. Scott, M. Hernandez, I. S. Burns, L. Levick, A. Cate, W. Kepner, D. Semmens, S. Miller, and P. Guertin. 2006. Automated Geospatial Watershed Assessment (AGWA): a GIS-based hydrologic modeling tool for watershed management and landscape sssessment. In: Proceedings of the 3rd Federal Interagency Hydrologic Modeling Conference, Reno, NV, 2-6 April 2006. Available at http://acwi.gov/hydrology/mtsconfwkshops/conf_proceedings/ 3rdFIHMC/1D_Goodrich.pdf. Accessed 1 July 2011.

9. Arnold, J. G., J. R. Williams, R. Srinivasan, K. W. King, AND R. H. Griggs. 1994. SWAT: Soil Water Assessment Tool. Temple, TX: US Department of Agriculture, Agricultural Research Service, Grassland, Soil and Water Research Laboratory. $19 \mathrm{p}$.

10. Weltz, M. A., L. Jolley, M. Nearing, J. Stone, D. Goodrich, K. Spaeth, J. Kiniry, J. Arnold, D. Bubenheim, M. Hernandez, and H. Wei. 2008. Assessing the benefits of grazing land conservation practices. Journal of Soil and Water Conservation 63:214A-217A.

11. Miller, S. N., D. P. Guertin, And D. C. Goodrich. 1996. Linking GIS and geomorphologic field research at Walnut Gulch Experimental Watershed. In: Proceedings of the 32nd
AWRA Annual Conference and Symposium on GIS and Water Resources, Ft. Lauderdale, F1., 22-26 September 1996. Herndon, VA, USA: American Water Resources Association. p. 327-335.

Authors are Research Hydraulic Engineer, USDA Agricultural Research Service Southwest Watershed Research Center, Tucson, AZ 85719, USA, dave.goodrich@ars.usda. gov (Goodrich); Professor, School of Natural Resources and the Environment, University of Arizona, Tucson, AZ 85721, USA (Guertin); Support Scientist (Burns), Research Agricultural Engineer (Nearing), Research Hydrologist (Stone), Agricultural Science Research Technician (Wei), Research Biologist and Research Leader (Heilman), and Hydrologist (Hernandez), USDA-ARS Southwest Watershed Research Center, Tucson, AZ 85719, USA; Rangeland Management Specialist, USDA Natural Resources Conservation Service Central National Technology, Fort Worth, TX 76115, USA (Spaeth); Research Leader, USDA-ARS Northwest Watershed Research Center, Boise, ID 83712, USA (Pierson); Assistant Professor (Paige) and Associate Professor (Miller), Department of Renewable Resources, University of Wyoming, Laramie, WY 82071, USA; Research Ecologist, Landscape Ecology Branch, US Environmental Protection Agency, Las Vegas, NV 89119, USA (Kepner); Professor and Extension Specialist (Ruyle) and Professor (McClaran), School of Natural Resources and the Environment, University of Arizona, Tucson, AZ 85721, USA; Acting Research Leader, USDA-ARS Exotic and Invasive Weed Research Unit, Reno, NV 89512, USA (Weltz); and Rangeland Ecologist, USDA-NRCS, Napa, CA 94558, USA (Jolley). Support for this research as provided by the US Department of Agriculture Rangeland Research Program and the NRCS Conservation Effects Assessment Program (CEAP; Web site available at: www.nrcs.usda.gov/TECHNICAL/ NRI/ceap). USDA is an equal opportunity provider and employer. 